\title{
Aftermath of the Monetarist Clash with the Federal Reserve Before and During the Volcker Era
}

Anna J. Schwartz

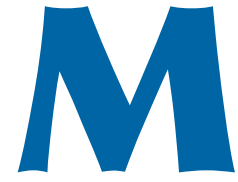

onetarists 40 years ago had a double objective. They sought to persuade the economics profession that (i) monetary policy, not fiscal policy, was the key to economic stability and (ii) the control of inflation required limiting money balances, not incomes policies and wage controls. Monetarists also sought to persuade the Federal Reserve to alter the way it conducted monetary policy to conform to monetarist doctrines. In the three years (1979-82) under Volcker, disinflationary monetary policy, announced as being designed to contain growth in money aggregates, brought down the U.S. inflation rate from 10 percent to 4 percent. Since then the inflation rate has remarkably declined even more. A victory for monetarism? During the Volcker era monetarists did not think so.

Missing from the retrospective on the Volcker era at the special conference held at the Federal Reserve Bank of St. Louis was a consideration of the complaints against the Federal Reserve expressed by monetarists. The conference papers celebrated Volcker's achievement and deemed the changes in monetary theory and practice since his time as virtually unqualifiedly successful.

I propose to review past monetarist strictures (Shadow Open Market Committee, 1974-1982) and ask whether current Federal Reserve practice provides a satisfactory response to them. Twenty-five years after the Volcker era, has the contest between the U.S. central bank and its critics been resolved?

\section{THE MONETARIST CRITIQUE BEFORE THE VOLCKER ERA}

The critique centered on alleged faulty procedures by the Federal Open Market Committee
(FOMC) in conducting monetary policy and on the undesirable outcomes of these procedures. The litany of faults included the following examples and prescriptions for changes in procedure.

- Fed monetary policy is based on a nominal short-term interest rate, which is an unreliable guide. The Fed interprets a low rate as indicating monetary ease, a high rate as indicating monetary tightening. A low rate, however, may in fact be consistent with contraction if the growth rate of the quantity of money has been declining, and a high rate may be consistent with expansion if the growth rate of the quantity of money has been rising. Moreover, monetary authorities who rely on an interest rate instrument are prone to delay a needed increase to combat inflation because they believe that it will produce a rise in the unemployment rate. Action is often late and excessive.

Prescription: Monetary policy should be based on a credible, pre-announced, longrun stable growth rate of a monetary aggregate, preferably the monetary base or M2.

- The Fed instructs the Manager of open market operations at the Federal Reserve Bank of New York to maintain money market conditions that it specifies in its directive to him, with a proviso that credit does not unduly expand. The directive leaves open to the Manager the interpretation to be placed on money market conditions and therefore makes it impossible to hold him accountable for the open market operations that he chooses to execute. Prescription: The Fed should not conduct 
monetary policy using money market conditions, which have no precise definition, as their rationale.

- The horizon of the Fed is the short interval between FOMC meetings. The short horizon is inconsistent with forward-looking forecasting. Policy is directed to transitory events that it cannot influence. Prescription: The Fed horizon should extend beyond several quarters ahead. It should aim at a long-run target, and that target should be the rate of monetary growth that is expected to produce price stability.

- The Fed engages in fine-tuning, attempting to promote economic growth and employment by lowering interest rates until inflation looms, whereupon it reacts by raising interest rates and slowing economic growth and employment. The policy creates a gostop economy. Prescription: The Fed should abjure fine-tuning. It destabilizes the economy. Properly designed monetary policy can achieve price stability, not real economic activity.

- The Fed asserts that its exercise of discretion in moving the short-term nominal interest rate enables it to offset short-term fluctuations in real economic activity. Monetarists, however, argue that discretion is destabilizing. Prescription: Fed policy should embody the view that monetary policy stabilizes real economic activity when it is based on a rule that requires low, stable money growth.

\section{THE MONETARIST CRITIQUE DURING THE VOLCKER ERA}

I begin with a brief review of the disinflationary monetary policy that Volcker presided over. I then note monetarist criticisms.

In 1975, Congress passed Joint Congressional Resolution 133 requiring the Fed to adopt oneyear money growth targets. In October 1979, the Fed described the reason for the new procedures that Chairman Volcker introduced as more precise control of monetary growth. The Fed announced the target growth rate each year on a base equal to the actual level of the money stock in the fourth quarter of the preceding year. In the late 1970s, the above-target money growth in one year was built into the next year's target. In 1981, the belowtarget money growth was built into the 1982 target. The resulting base drift contributed to instability of money growth.

In advance of the new procedures, in the early 1970s, the Fed began direct targeting of the federal funds rate within a narrow band specified by the FOMC each time it met. If the Fed was slow in raising the target and, when it did raise the target, did not raise it enough, as total nominal spending rose, rapid money growth resulted and, accordingly, higher inflation growth.

The new procedures, adopted on October 6, 1979, replaced direct federal funds rate targeting with nonborrowed-reserves targeting. The new procedure was intended to supply banks with the average level of total reserves (the combination of discount window borrowing and open-market provision of nonborrowed reserves) that would produce the rate of monetary growth the FOMC desired over the period from a month before a meeting to some future month, without regard for the accompanying possible movement of the federal funds rate outside a widened range of 400 basis points.

At the October 5, 1982, meeting, the FOMC abandoned nonborrowed-reserves targeting. It concluded that short-run control of monetary aggregates was inferior to interest rate control. The Fed's difficulty with nonborrowed-reserves targeting was attributed to the unreliability of the demand function for discount window borrowing on which its operating procedure depended.

Observers who were not monetarists described the Fed's new procedure as a subterfuge. It permitted the Fed to raise the federal funds rate to unprecedented heights while alleging that it was not itself acting on the rate. It was containment of the M1 aggregate (as then defined) that produced the interest rate result.

For monetarists, the Fed's new procedure was a travesty of their prescription of a pre-announced steady and predictable rate of growth of a monetary aggregate. The Fed missed its monetary 
growth target more often than it hit it. Monetary growth fluctuated over a wide range. The volatility of quarter-to-quarter rates of monetary growth during the three-year period was three times as high as earlier (Friedman, 1984). Two recessions punctuated the three-year period: January 1980July 1980 (produced by Carter administration credit controls); and July 1981-November 1982 (produced by the new Volcker procedures).

The Fed at bottom probably remained unconvinced that it was desirable to base monetary policy on control of a monetary aggregate. That is why in 1968 it shifted from contemporaneous to lagged reserve requirements despite the fact that lagged reserve requirements impaired control of the quantity of money. That was simply not a Fed priority.

Nevertheless, as noted, the inflation rate subsided under the new procedure.

\section{THE AFTERMATH}

Twenty-five years have elapsed since the Volcker era. How have the monetarists fared on the two fronts on which they promoted views that neither the academic community nor the Fed initially accepted?

The monetarist debate with the economics profession is in abeyance, but monetarist tenets are now incorporated in mainstream economics. Indeed, the profession now embraces the beliefs that money matters, that inflation can be controlled by monetary policy, that there is no long-run trade-off between inflation and unemployment, that there is a distinction between nominal and real interest rates, and that policy rules help anchor stable monetary policy.

The monetarist battle with the Fed was also not fought in vain. Whatever the shortcomings of the Volcker procedure, it marked the onset of central bank acknowledgment that their key responsibility was to control inflation. By 2004, central banks in all advanced countries have adopted implicit or explicit targets for future inflation. Their success in meeting their inflation targets has gained them credibility. The target has become the public's expected inflation rate. Growth rates of monetary aggregates tend to be moderate and stable. Although central banks, with the exception of the European Central Bank, ignore money aggregates in their theoretical frameworks and their practice, a possibly unintended result of their success in controlling inflation is that money aggregates currently have no predictive power with respect to prices. Before the Volcker era, money aggregates swelled as economic activity expanded and grew less as economic activity faltered, forecasting higher and then lower prices. This pattern is no longer observable.

What does this development teach us about monetarism's past disagreements with the Fed? Monetarism lost the battle for a monetary aggregate to replace the federal funds rate as the Fed's target, but it won the real goal that it sought, namely, long-run stable growth of an aggregate with no predictive power for prices.

Will this happy outcome endure? Time will tell.

\section{REFERENCES}

Friedman, Milton. "Lessons from the 1979-82 Monetary Policy Experiment." American Economic Review, May 1984, 74(2), pp. 397-400.

Shadow Open Market Committee. Semi-annual Policy Statement. Unpublished manuscripts. Rochester, NY: University of Rochester, 1974-1982. 
